\title{
The comparison of probiotic monocultures influence on organochlorine pesticides changes in fermented beverages from cow and goat milk during cold storage
}

\author{
Agata Witczak ${ }^{7 *}$, Anna Mituniewicz-Małek²

\begin{abstract}
'West Pomeranian University of Technology, Faculty of Food Science and Fisheries, Department of Toxicology, Szczecin, Poland

${ }^{2}$ West Pomeranian University of Technology, Faculty of Food Science and Fisheries, Department of Dairy Technology and Food Storage, Szczecin, Poland

*Corresponding author: E-mail: agata.witczak@zut.edu.pl
\end{abstract}

\section{Abstract}

\begin{abstract}
The effect of selected probiotic monocultures addition as a method of organochlorine pesticides (OCP) residues reduction in fermented beverages manufactured from cow and goat milk during cold storage was examined. Supplementation of traditional yogurt starter by single monoculture or a mixture of two monocultures has resulted in a decrease of OCPs in products during cold storage. Extension of the cold storage period up to 14 days resulted in further losses in the content of the analysed compounds. Regardless of the milk type used for beverage production, beverages prepared from the mixture of two monocultures (Lb. acidophilus LA-5 and Bifidobacterium BB-12) showed significantly greater decrease of pesticides content in comparison to beverages containing only LA-5. The maximum decrease (from $5.39 \%$ to $20.7 \%$ in OCP was determined during the 14-day cold storage, and was few percent higher in beverages manufactured from goat milk.
\end{abstract}

Key words: fermented beverages, probiotic bacteria, Lb. acidophilus, Bifidobacterium, organochlorine pesticides residues (OCPs)

\section{Introduction}

Cow milk is the most widely manufactured and consumed product in the world wherein production in the EU countries constitutes ca. $24 \%$ of the world production (Polish share equals $8.3 \%$ ) (Statistical Yearbook, 2016). Although in recent years, goat milk has become increasingly popular, as it is seen as an ecological and healthy product. At present, the global production of goat milk is estimated at 2025 million L of which $26 \%$ is the EU production (Górska, 2015). Both, cow and goat milk can be used as raw materials for the production of yogurts and other fermented beverages. The most noticeable difference between goat and cow yogurts appears in the curd texture of the final product. Goat milk yogurt gel is more delicate and less viscous, compared to its cow milk equivalent (Park et al., 2007). 
In the age of healthy eating, the consumer draws particular attention to the composition of consumed products, amount and type of used additives and problem of the occurrence of many contaminants in dairy products. Particularly harmful and persistent are organochlorine xenobiotics, which significantly reduce the quality of the consumed products (Zhang et al., 2006; Abou Donia et al., 2010). The occurrence of organochlorine xenobiotics in caw and goat milk is one of biological indicators of environmental pollution and, consequently, food contamination.

Plant protection products (PPP), including organochlorine pesticides (OCP s), are a large group of diverse chemical compounds used to fight insects, weeds, parasitic fungi, rodents, etc. On the one hand, their long-term use has contributed to the growth of productivity of many agricultural crops. But on the other hand, it has created a significant threat to the environment and human health. Long-term studies have shown that the persistence of pesticides in the environment and their biodegradation resistance, as well as the potential for more toxic metabolites, are a decisive factor in considering the extent of their use and have significant health implications. Among others, they belong to neurotropic poisons, which compromise the balance of central neurotransmitter systems (catecholamine, indoleamine and GABA) and inhibit the activity of pyrophosphatases of central nervous tissue involved in the transmission of relay substances (Rafalska and Krauze, 2016).

Some chlorinated hydrocarbons (DDT, heptachlor) are inhibitors of respiratory cycle enzymes and carbohydrate phosphate metabolism. The acute neurotoxic effects of DDT are related to its direct effect on the sensory and motor nerves in the cerebral cortex and the inhibition of the sodium-potassium pump activity of the presynaptic membrane of neurons. Cyclodiene insecticides violate amino acid metabolism and cause an increase in the ammonia content in the brain. It is believed that different stimulation or depressive action of $\mathrm{HCH}$ isomers are due to their varying ability to penetrate axonal cell membranes (Rafalska and Krauze, 2016).
The compounds belonging to the OCPs, as part of multisystemic poisons, also damage other organs, primarily the liver and kidneys, which participate in detoxification and excretion of harmful metabolites from the body (Mrema et al., 2013). Due to the lipophilic nature of these compounds, they tend to accumulate in tissues and organs of dairy animals. Milk represents one of the main routes of excretion from the body, and the degree of penetration of the tested pesticides in the chain "feed - animal - milk” ranges from 2 to $80 \%$. Carry-over rate for some pesticides is estimated as: $\mathrm{HCB} \leq 79 \%$, $\mathrm{aHCH}$ in the range of $<1-21 \%, \beta \mathrm{HCH} 15-54 \%, \mathrm{\gamma HCH}$ 2-4 \%, dieldrin 18-40 \%, p,p'DDT $4 \%$ and p,p'DDE $80 \%$ (Blüthgen, 2000).

It can be stated that the degradation of these compounds might be carried out not only by photochemical, chemical (e.g. oxidation, reduction, hydrolysis) or thermal decomposition (Biegańska, 2007), but also due to the activity of microorganisms (Phillips et al., 2005). Some studies, concerning initially the degradation of these compounds in contaminated soil (Sudharshan et al., 2013), also demonstrated the possibility of reducing the residue of these xenobiotics during food production (Abou-Arab, 1997, 1999).

Considering the possibility of causing many negative health effects to humans and the insufficient amount of research in this field, it was advisable to determine the possibility for reducing the residues of analysed pesticides by probiotic monocultures used in the production of milk-based fermented beverages manufactured from cow and goat milk during cold storage. Therefore, the main objective of this work was to examine the effect of adding probiotic monocultures Lactobacillus acidophilus LA-5 and Bifidobacterium animalis subsp. lactis BB-12 on the changes in content of selected organochlorine pesticides (aHCH, a-hexachlorocyclohexane, $\mathrm{BHCH}, \beta$-hexachlorocyclohexane, $\gamma \mathrm{HCH}$ - $\gamma$-hexachlorocyclohexane, heptachlor, heptachlor epoxide isomer $\mathrm{B}$, dieldrin, endrin, op'DDE, pp'DDE, op'DDD, op'DDT, pp'DDD, pp'DDT) in the fermented beverages manufactured from cow and goat milk during cold storage (temp. $5 \pm 7^{\circ} \mathrm{C}$ ). 


\section{Materials and methods}

\section{Preparation of fermented beverages as the test materials}

Test materials were fermented beverages from cow and goat milk, prepared under laboratory conditions by the thermostatic method. The raw material for their production was cow and goat milk purchased from two farms in Poland (West Pomeranian Province). The milk was pasteurized with the tank method $\left(85^{\circ} \mathrm{C} / 20-30 \mathrm{~min}\right)$ and then cooled to $42{ }^{\circ} \mathrm{C}$. At the next stage, both types of milk were divided into three batches, which were inoculated with a suitable, previously activated culture (starter culture). A commercial yogurt culture YC-X16 (Chr. Hansen, Poland), containing Streptococcus thermophilus and Lactobacillus delbrueckii subsp. bulgaricus, was added to the first batch of cow milk and obtained yogurt beverage was the control sample (A) (Table 1). The remaining two batches of milk, except of yogurt starter YC-X16, were inoculated respectively with monoculture $L b$. acidophilus $L A-5$ and a mixture of two monocultures, i.e. Lb. acidophilus $L A-5$ and Bifidobacterium animalis subsp. lactis BB-12, obtained two bio-yogurts were marked as $A 1$ and $A 2$. Similarly, fermented beverages from goat milk, i.e. yogurt (B), being also the control sample, as well as two bio-yogurts (B1 and B2), were also produced. All in all, 6 variants of fermented beverages were prepared (Table 1). In the prepared cow and goat milk bio-yogurts, the yogurt starter as well as $L A-5$ and $B B-12$ probiotic monocultures were used in a 1:1:1 ratio. The yogurt and probiotic starters were obtained by incubation of culture portion $\left(0.6 \mathrm{~g} \mathrm{~L}^{-1}\right)$ in sterile skimmed milk, conducted at $42{ }^{\circ} \mathrm{C}$ for $6-8 \mathrm{~h}$, and at $37^{\circ} \mathrm{C}$ for $7-8 \mathrm{~h}$, respectively.

Before proceeding to acidification (incubation) of the test beverages, each of the individual samples $(200 \mathrm{~mL})$ was contaminated with a selected group of organochlorine pesticides in the form of n-hexane solution (S-20168, AccuStandard USA). The target concentration of each of the analysed

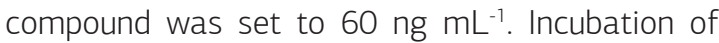
experimental beverages was conducted at $42{ }^{\circ} \mathrm{C}$ to obtain a concise curd ( $\mathrm{pH}$ 4.6-4.8) and then, the beverages were cooled to the $5 \pm 1{ }^{\circ} \mathrm{C}$ and kept under these conditions. The analysed samples were randomly collected at the $1^{\text {st }}, 7^{\text {th }}, 14^{\text {th }}$ and $21^{\text {st }}$ day of cold storage in 10 packages of each variant.

Parameters such as density, acidity, and total solids were determined directly after delivery to the laboratory. Density was determined by the aerometric method, and acidity (in ${ }^{\circ} \mathrm{SH}$ ) - by the titration method according to the National Standard (AOAC, 1995). Fat content was determined using the Gerber's method (PN-ISO 488: 2010), while the dry mass content was measured gravimetrically. Protein content was determined using the spectrophotometric method (Cygański, 1993).

TABLE 1. Variations of prepared fermented beverages

\begin{tabular}{l|l|l}
\hline & Sample symbol & Sample description \\
\hline $\begin{array}{l}\text { Fermented } \\
\text { beverages from } \\
\text { cow milk }\end{array}$ & A & Cow milk yogurt with YC-X16 yoghurt starter \\
\cline { 2 - 3 } & A1 & $\begin{array}{l}\text { Cow milk bio-yogurt with YC-X16 yoghurt starter and Lb. acidophilus } \\
\text { LA-5 monoculture }\end{array}$ \\
\cline { 2 - 3 } $\begin{array}{l}\text { Fermented } \\
\text { beverages from } \\
\text { goat milk }\end{array}$ & A2 & $\begin{array}{l}\text { Cow milk bio-yogurt with YC-X16 yoghurt starter and Lb. acidophilus } \\
\text { LA-5 and Bifidobacterium animalis subsp. lactis BB-12 monocultures }\end{array}$ \\
\cline { 2 - 3 } & B1 & $\begin{array}{l}\text { Goat milk yogurt with YC-X16 yoghurt starter } \\
\text { LA-5 monoculture }\end{array}$ \\
\cline { 2 - 3 } & B2 & $\begin{array}{l}\text { Goat milk bio-yogurt with YC-X16 yoghurt starter and Lb. acidophilus } \\
\text { LA-5 and Bifidobacterium animalis subsp. lactis BB-12 monocultures }\end{array}$ \\
\hline
\end{tabular}


Prior the analysis of organochlorine compounds, the samples were freeze-dried in a LyoLab 3000 apparatus, and stored at $-18{ }^{\circ} \mathrm{C}$ in sealed glass containers until analysis. Determination of organochlorine compounds in yoghurts and bio-yogurts was done according to the methods described by Witczak et al. (2013). Analyses were performed in three replications, using the following GC/MS setting: carrier gas-helium; pressure: $0.061 \mathrm{Mpa}(8.9$ psi); flowrate: $0.8 \mathrm{~mL} \mathrm{~min}{ }^{-1}$, column (HP-5MS/60.0 $\mathrm{m}$; ID $250 \mathrm{~mm}, 2.25 \mathrm{~mm}$ film thickness of the active phase) oven temperature: start from $90{ }^{\circ} \mathrm{C}(0.5$ $\mathrm{min})$, increase $7^{\circ} \mathrm{C} \mathrm{min}^{-1}, 220^{\circ} \mathrm{C}$ (12 min), increase $6^{\circ} \mathrm{C} \mathrm{min}{ }^{-1}, 285^{\circ} \mathrm{C}$ (7min), increase $5^{\circ} \mathrm{C} \mathrm{min}^{-1}, 295^{\circ} \mathrm{C}$ (6 min) (post run). Time analysis of one sample was 54.9 min. Detector: mass spectrometer (HP5973).

The quantification of concentration and recovery was carried out by contaminated samples (with mixed OCP standards, S-20168, AccuStandard USA) and by the internal standard (cis-chlordane, 80 ng mL-1, N1 1480-10MG, Supelco, USA). The limit of detection (LOD) for each compound was determined as the concentration in the extract which produced an instrumental response at two different ions to be monitored with a signal to noise ratio of 3:1 for the less sensitive signal (Commission Directive 2002/63/EC).

A blank method was included for every ten samples. The LOD for each pesticide was $0.01 \mathrm{ng}$ $\mathrm{mL}^{-1}$ on average. The LOQ of OCPs were as follows: pp'DDE (0.06 ng mL $\left.\mathrm{m}^{-1}\right)$, pp'DDD (0.05 $\left.\mathrm{ng} \mathrm{mL}^{-1}\right)$, pp'DDT (0.01 ng $\mathrm{mL}^{-1}$ ), a, $\beta, \gamma H C H\left(0.04 \mathrm{ng} \mathrm{mL}^{-1}\right.$ ). The average recovery of the organochlorine pesticides was ranged from 69.6 to $99.8 \%$.

\section{Statistical analysis}

The statistical analysis of study results was carried out with Statistica 10.0 software. The analysis of variance ANOVA was preceded by the Levene homogeneity test and Kolmogorov-Smirnov normal distribution test (K-S test). Coefficients of Pearson correlation were determined as well. The significance of differences between mean values was evaluated with the Tukey test $(\mathrm{P}<0.05)$.

\section{Results and discussion}

\section{Basic chemical composition of the raw materials - cow and goat milk}

Cow milk was richer in protein and fat compared to goat milk (1.2 and 1.4 times, respectively) while differences in acidity and density were not significant $(P<0.05)$ (Table 2). The content of protein and fat in both raw materials was slightly different from the data available in the literature (Eissa et al., 2011; Costa et al., 2016). The composition of milk may, however, vary depending on the breed, lactation phase, genetic and environmental factors, animal health or feeding method. From a technological point of view, the appropriate protein and fat content in milk is extremely important because it favours obtaining the proper qualities of the final product. Furthermore, the titratable acidity and the $\mathrm{pH}$ of the tested raw materials (Table 2) were at similar levels as reported by other authors (Gomes et al., 2013 Costa, et al., 2016).

TABLE 2. The physicochemical properties of the raw material for the production of fermented beverages

\begin{tabular}{|c|c|c|c|c|c|}
\hline 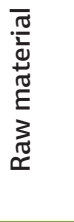 & 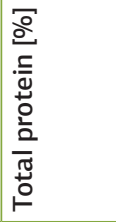 & 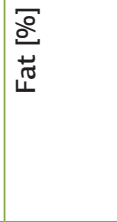 & $\frac{I}{\alpha}$ & 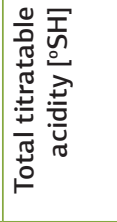 & 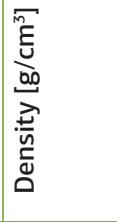 \\
\hline $\begin{array}{l}\text { Cow } \\
\text { milk }\end{array}$ & $\begin{array}{r}3.26 \\
\pm 0.21\end{array}$ & $\begin{array}{r}4.60 \\
\pm 0.10\end{array}$ & $\begin{array}{r}6.73 \\
\pm 0.22\end{array}$ & $\begin{array}{r}6.90 \\
\pm 0.30\end{array}$ & $\begin{array}{r}1.03 \\
\pm 0.10\end{array}$ \\
\hline $\begin{array}{l}\text { Goat } \\
\text { milk }\end{array}$ & $\begin{array}{r}2.69 \\
\pm 0.14\end{array}$ & $\begin{array}{r}3.38 \\
\pm 0.13\end{array}$ & $\begin{array}{r}6.89 \\
\pm 0.18\end{array}$ & $\begin{array}{r}6.07 \\
\pm 0.26\end{array}$ & $\begin{array}{r}1.03 \\
\pm 0.11\end{array}$ \\
\hline
\end{tabular}

Residues of OCPs in cow and goat milk

Considering the raw material used for the production of fermented beverages, in addition to op'DDD, pp'DDT and heptachlor, goat milk was significantly richer $(\mathrm{P}<0.05)$ in pesticides, compared to cow milk. Lower pesticide concentrations were determined in goat milk (0.04 $\mathrm{ng} \mathrm{g}^{-1}$ milk fat, op'DDD) and the highest (3.85 $\mathrm{ng} \mathrm{g}^{-1}$ milk fat, heptachlor) in cow milk (Table 3). 
TABLE 3. Residues of OCPs in raw milk intended for fermented beverages production

\begin{tabular}{l|l|l|l|l}
\hline Compounds & Cow milk & & Goat milk & \\
\hline & Content, $\mathbf{n g} \cdot \mathbf{g}^{-1}$ milk fat & CV, $\%$ & Content, ng. $\mathbf{g}^{-1}$ milk fat & CV, \% \\
\hline aHCH & $0.12 \pm 0.01^{1}$ & 4.92 & $0.17 \pm 0.01$ & 7.19 \\
\hline$\beta H C H$ & $0.44 \pm 0.03$ & 7.27 & $0.81 \pm 0.01$ & 1.11 \\
\hline YHCH & $0.24 \pm 0.04$ & 14.8 & $0.68 \pm 0.05$ & 7.65 \\
\hline pp'DDE & $1.95 \pm 0.22$ & 11.4 & $3.49 \pm 0.10$ & 2.89 \\
\hline op'DDE & $0.04 \pm 0.01$ & 11.4 & $0.10 \pm 0.01$ & 8.00 \\
\hline pp'DDD & $0.07 \pm 0.01$ & 8.82 & $0.15 \pm 0.01$ & 5.88 \\
\hline op'DDD & $0.05 \pm 0.004$ & 8.00 & $0.04 \pm 0.003$ & 7.14 \\
\hline pp'DDT & $1.03 \pm 0.03$ & 2.92 & $0.68 \pm 0.02$ & 3.52 \\
\hline op'DDT & $0.37 \pm 0.03$ & 7.24 & $0.50 \pm 0.04$ & 8.33 \\
\hline heptachlor & $3.85 \pm 0.24$ & 6.32 & $2.12 \pm 0.13$ & 5.95 \\
\hline heptachlor epoxide & $1.36 \pm 0.16$ & 11.9 & $1.81 \pm 0.21$ & 11.4 \\
\hline dieldrin & $1.19 \pm 0.13$ & 11.3 & $0.93 \pm 0.06$ & 6.44 \\
\hline endrin & $0.85 \pm 0.02$ & 2.22 & $0.79 \pm 0.08$ & 10.5 \\
\hline
\end{tabular}

'X \pm SD; $\mathrm{aHCH}$ - a-hexachlorocyclohexane; $\beta \mathrm{HCH}$ - $\beta$-hexachlorocyclohexane; $\gamma \mathrm{HCH}$ - $\gamma$-hexachlorocyclohexane;

pp'DDE - 1,1-bis-(4-chlorophenyl)-2,2-dichloroethene; pp'DDD - 1-chloro-4-[2,2-dichloro-1-(4-chlorophenyl)ethyl]benzene;

pp'DDT - 1,1'-(2,2,2-Trichloroethane-1,1-diyl)bis(4-chlorobenzene)

\section{Changes of OCPs in fermented beverages}

Based on the obtained results, it was found that the addition of both bacterial starter YC-X16 and bacterial monocultures (Table 1) did not significantly affect $(P>0.05)$ changes in the fat content of the tested products, with an average content of $3.38 \%$ in goat milk beverages and $4.60 \%$ in cow milk beverages.

\section{Effect of yogurt starter and monoculture supplement on OCPs changes during cold storage}

Finally, only products obtained after 7 and 14 days of cold storage were considered, and those after 21 days were rejected because they were unsuitable for consumption, from the consumer point of view (mold formation was observed at the surface of fermented beverages).

According to Tukey test $(P<0.05)$, after the first day of storage there were no significant changes the analysed pesticides' content $(0.4 \%$ to 0.07 $\%)$ in contaminated samples with regard to the applied microflora ranging from. The changes recorded after $7^{\text {th }}$ and $14^{\text {th }}$ days of cold storage indi- cated significant $(P<0.05)$ losses (or increases) of the analysed compounds in the tested fermented beverages, are shown in the Table 4 .

Based on the results of the experiment, it was noted that in beverages (marked A and B) fermented with the traditional yogurt culture YC-X16 (Table 1), significant losses in the analysed compounds were observed during cold storage. In the case of cow milk products, these variations ranged from $-5.17 \%$ (heptachlor) to $-69 \%$ (aHCH) (after 7 days) and from -9.2 (pp'DDT) to $-96 \%$ (aHCH) after 14 days of cold storage. In the case of fermented beverages obtained from goat milk, the changes ranged from $-5.83 \%$ (pp'DDT) to $-52.5 \%(\mathrm{BHCH})$ after 7 days of storage and from $-9.27 \%$ (pp'DDT) to $-89.4 \%$ (op'DDT) after 14 days of cold storage (Table 4).

It could also be noticed that monoculture $L b$. acidophilus LA-5 used in bio-yogurts from cow milk (A1) and goat milk (B1) caused an additional reduction in the test compounds (Table 4).

After 7 days of storage significant $(P<0.05)$ losses in pesticide content (from -0.89\% pp'DDD to $-30.6 \% \mathrm{aHCH}$ ) could be observed in beverages from cow milk (A1), and after 14 days from $9.18 \%$ (op'DDT) to $-36.6 \%$ (heptachlor) (Table 4). 
TABLE 4. Effect of addition of probiotic culture to the fermented beverages with YC-X16 yogurt culture (Streptococcus thermophilus and Lactobacillus delbrueckii subsp. bulgaricus) on changes in content of analysed compounds

\begin{tabular}{|c|c|c|c|c|c|c|c|c|}
\hline \multirow[t]{2}{*}{ OCPs } & \multicolumn{4}{|c|}{ after 7 days of storage } & \multicolumn{4}{|c|}{ after 14 days of storage } \\
\hline & A1 & B1 & A2 & B2 & A1 & B1 & A2 & B2 \\
\hline & \multicolumn{8}{|c|}{ Changes in content, \% } \\
\hline $\mathrm{aHCH}$ & -30.6 & -25.1 & -29.3 & -35.3 & 4.2 & -7.32 & 4.23 & -5.0 \\
\hline $\mathrm{BHCH}$ & -14.1 & -2.33 & 6.73 & 3.82 & 8.54 & 0.35 & 15.6 & 0.63 \\
\hline $\mathrm{\gamma HCH}$ & -22.3 & -9.77 & -36.3 & -25.5 & -14.2 & -20.0 & -14.4 & -39.5 \\
\hline heptachlor & -17.3 & -22.6 & -23.7 & -12.5 & -36.6 & -42.7 & -46.4 & -48.6 \\
\hline $\begin{array}{l}\text { heptachlor } \\
\text { epoxide }\end{array}$ & -7.29 & -33.3 & -19.3 & -28.3 & -1.04 & -15.9 & -5.07 & -16.8 \\
\hline op'DDE & -9.89 & -4.97 & -11.3 & -2.98 & -2.92 & 4.01 & -6.63 & -9.49 \\
\hline pp'DDE & -3.47 & -27.9 & -17.6 & -38.0 & -4.6 & -54.7 & -9.84 & -56.7 \\
\hline Dieldrin & -5.58 & 2.21 & -28.3 & -1.8 & -2.61 & -24.2 & -25.2 & -11.6 \\
\hline op'DDD & -2.19 & -11.8 & -11.1 & -15.5 & 3.33 & -5.8 & -8.49 & -10.6 \\
\hline Endrin & -3.6 & 5.77 & 3.46 & -32.0 & -10.1 & -3.92 & -24.5 & -19.8 \\
\hline op'DDT & -4.7 & -4.86 & -18.9 & -10.0 & 9.18 & -0.86 & -20.3 & -0.77 \\
\hline pp'DDD & -0.89 & -5.16 & -5 & -10.6 & -5.96 & -2.35 & -9.81 & -13.1 \\
\hline pp'DDT & -5.42 & -10.9 & -10.5 & -17.8 & -17.4 & -17.7 & -26.9 & -38.0 \\
\hline Average & -9.79 & -11.6 & -15.5 & -17.4 & -5.39 & -14.7 & -13.7 & -20.7 \\
\hline
\end{tabular}

A1 - cow milk bio-yogurt with LA-5 monoculture, A2 cow milk bio-yogurt with LA-5 and BB-12 monoculture, B1 - goat milk bioyogurt with LA-5 monoculture, B2 - goat milk bio-yogurt with LA-5 and BB -12 monoculture)

In goat milk beverages (B1) an additional decrease from $2.21 \%$ (dieldrin) to $-33.3 \%$ (heptachlor epoxide) after 7 days of cold storage was determined, and after 14 days from $4.01 \%$ (op'DDE) to $-54,7 \%$ (pp'DDE) (Table 4).

In bio-yogurts obtained using the mixture of probiotic monocultures $\mathrm{LA}-5$ and BB-12, it was found that, microflora ( $L b$. acidophilus $L A-5$ and $B i-$ fidobacterium BB-12) contributed to the changes in the content of tested pesticides in both types of bio-yogurts (cow (A2) and goat (B2) milk), during storage (Table 4).

In beverages from cow milk (A2), the pesticide content changes ranged from $-6.73 \%(\mathrm{BHCH})$ to $-36.3 \%(\mathrm{\gamma HCH})$ after 7 days of storage, and after 14 days from $15.6 \%(\mathrm{BHCH})$ to $-46.4 \%$ (heptachlor) (Table 4).

In goat milk beverages (B2), additional decrease from $3.82 \%(\mathrm{BHCH})$ to $-38.0 \%$ (pp'DDE) was no- ticed after 7 days of cold storage, and after 14 days from $0.63 \%(\mathrm{BHCH}$ ) to - $56.7 \%$ (pp'DDE) (Table 4).

The correlation coefficients $r$ between changes in the content of the analysed pesticides and the storage time of fermented beverages ranged from -0.99 to 0.45 .

Significantly greater loss of pesticides in the probiotic beverages prepared from the mixture of two monocultures ( $L b$. acidophilus LA-5 and Bifidobacterium $\mathrm{BB}-12$ ) - $\mathrm{A} 2$ and $\mathrm{B} 2$ were detected in both milk types, as compared to the beverages containing only LA-5 (Table 4). Taking into account the type of raw material (cow and goat milk) used for the production of fermented beverages, it was noted that the average content losses of the analysed compounds under the influence of the bacterial microflora were higher by several per cents in beverages manufactured from goat milk. This was probably due to differences in the properties of cow and goat milk. 
In Poland, there is a constantly growing interest in fermented beverages, which are considered as a healthy part of the diet. In addition to many prohealth qualities, they also tend to accumulate toxic substances from the environment.

The OCPs analysed in this work are lipophilic. However, fat content in milk is not the only factor influencing the amount of accumulated contaminants (Witczak, 2017). The degree of the environmental pollution and general conditions on the cattle farms might be of a greater importance. Other individual factors influencing the contamination of animal organisms with chemicals and their release mechanisms along with secretions of milk glands (Salem et al., 2009) cannot be excluded. In the case of goat farms, where free range flocks are preferred, pollution of environmental origin cannot be avoided, for example ingesting it with more diverse, often accidental food. As several authors have already pointed out, many of these compounds are legacy of the last century, and they are undoubtedly persistent organochlorine pesticides, classified as POPs (Persistent Organic Pollutants).

The decomposition of these compounds is primarily biochemical, but can also result from photochemical and chemical reactions (e.g. oxidation, reduction, hydrolysis, interactions with free radicals and nucleophilic substitution with water). It is worrying to the consumer that some pesticide disintegration products may be more toxic than the starting compounds (Ortiz-Hernández et al., 2013).

It is believed that the causes of changes in the content of individual isomers of the test compounds during the production and storage of fermented beverages may be numerous. Under anaerobic conditions, the major products of $\mathrm{HCH}$ metabolism are tetrachlorocyclohexene (TCCH), and under aerobic conditions - pentachlorocyclohexene (PCCH). The factor that favours this metabolism is UV radiation (EHC, 1991). Further decomposition leads to the formation of chlorophenols and chlorobenzenes, and in some cases to HCB. The final products are usually: methane, carbon dioxide, hydrogen and chlorine (Phillips et al., 2005).

The insecticide heptachlor belonging to cyclodienes, under UV exposure, can undergo intramolecular photocycling, leading to the formation of photoheptachlor, which is characterized by greater toxicity and stability in the environment. It has also been observed that some bacteria can cause slow conversion of lindane to isomers $a, \beta$ and $\delta$. The physical properties and stability of each isomer differ due to the different orientation of the chlorine atoms in each molecule (axial or parallel). The most stable isomer is $\mathrm{BHCH}$ (Phillips et al., 2005).

The main metabolites of DDT decomposition are DDE and DDD. The decomposition of the DDE metabolite undergoes further transformations leading to the formation of 4,4'-dichlorobiphenyl. The most of the studies investigated the possibility of DDT decomposition under the influence of bacteria living in the soil. It has been shown, inter alia, that Streptomyces sp. strain D3 showed a $77 \%$ degradation rate (Wang et al., 2017).

Based on the results of the experiment presented in this work, the changes in pesticides from the OCPs group have been observed during the storage of fermented beverages, both from cow and goat milk. It was noted that, in addition to the changes caused by bacteria contained in YC-X16 yogurt starter (Streptococcus thermophilus and Lactobacillus delbrueckii subsp. bulgaricus), additional changes were probably caused by the addition of probiotic monocultures. In yogurts manufactured with only YC-X16 starters, after 14 days of storage, the losses of analysed pesticides ranged from a few to several dozens per cents, and the maximum reached $96 \%$ for aHCH in cow milk yogurt and $89.4 \%$ for op'DDT in goat milk yogurt.

It was noted that, depending on whether this additive was composed of one monoculture LA- 5 (samples A1 and B1) or two at the same time, LA-5 and BB-12 (samples A2 and B2), and depending on the type of raw material used (cow milk or goat milk), changes in pesticide content during cold storage differed significantly $(P<0.05)$.

As it was demonstrated by Abou-Arab (1997), during the production of Ras cheese, under the influence of Streptococci, lactic acid bacteria and yeast, there was a reduction $\Sigma$ DDT in the range of 7.78 to $13.6 \%$ with respect to the content of these contaminants in milk. During the 6-month cold storage period, it was found that the losses ranged from 25.5 to $40.6 \%$.

The reduction of lindane during the production and the 3-day cold storage of yogurt ranged from 1.4 to $8.9 \%$ (Abou-Arab, 1999). There was also a 
$36.7 \%$ loss of lindane during the 6-month storage of Domiati cheese.

Based on the results of the experiment, it was concluded that the use of LA-5 monoculture for the production of beverages from cow milk (A1) resulted in significant $(\mathrm{P}<0.05)$ loss of analysed compounds after 7 days of storage, reaching $30.6 \%(\mathrm{aHCH})$, and after 14 days - $36.6 \%$ (heptachlor) (Table 4).

The changes in goat milk beverages (B1) occurred most likely due to the addition of LA-5 monoculture, which after 7 days of cold storage reached max. $33.3 \%$ (heptachlor epoxide), and after 14 days $54.7 \%$ (pp'DDE) (Table 4).

In the case of simultaneous use of the mixture of the two probiotic monocultures - LA- 5 and BB12 , significant $(P<0.05)$ changes in the content of tested pesticides during storage were found in both bio-yogurts (cow-A2 and goat-B2). In cow milk beverages (A2), after 7 days of storage, the simultaneous use of two monocultures (Table 1) resulted in maximum losses of $-36.3 \%$ for $\mathrm{\gamma HCH}$. A slight increase was observed for $\beta \mathrm{HCH}$ (6.7 \%), which increased to $15.6 \%$ after 14 days.

In comparison to sample, additional changes occurred in goat milk beverages (B2), after 7 days of cold storage and ranged from $3.8 \%(\mathrm{BHCH})$ to $-38.0 \%$ (pp'DDE), and after 14 days from $0.63 \%$ $(\mathrm{BHCH})$ to $-56.7 \%$ (pp'DDE), respectively.

As it has been shown, these changes were probably due to the addition of probiotic monocultures, since the storage conditions and other parameters were the same for all tested products. The importance of the changes was also influenced by the length of the cold storage period.

However, on the first day of storage, these changes were insignificant and minor. Significant changes in the tested compounds in probiotic beverages were observed after 7 days of storage, ranging on average from $-9.79 \%(\mathrm{~A} 1)$ to $-17.4 \%$ (B2) (Table 4). The arithmetic average of the losses of compounds formed during the 14-day cold storage ranged from $-5.39 \%(A 1)$ to $-20.7 \%(B 2)$. These results are partially consistent with those obtained by Abou-Arab (1997, 1999).

Since the compounds from the organochlorine pesticides group are exceptionally durable and have a low susceptibility to degradation, the thermal degradation of these compounds could not have occurred during low-temperature production of yogurt (up to $45^{\circ} \mathrm{C}$ ), only slight evaporation with steam could have occurred. An important factor influencing the possible changes in the content of OCPs in a fermented beverage in relation to the content in edible milk may be biodegradation under the influence of bacterial cultures.

Taking into account the above considerations, the biodegradation process of lipophilic, durable and relatively resistant to the degradation xenobiotic by some microorganisms deliberately added to dairy products, can be a good way to significantly reduce the exposure of the consumer. This is important because even small doses of these substances can be dangerous due to their accumulation in living organisms, that is to say, in raw materials of animal origin and in the human body.

\section{Conclusion}

During cold storage of fermented beverages produced from cow and goat milk, the losses of analysed pesticides content were observed in almost all samples. Studies have shown that, supplementation of traditional yogurt starter by single monoculture or a mixture of two monocultures has resulted in a decrease in the content of analysed OCPs. The importance of the changes of pesticides in the fermented beverages was also influenced by the length of the cold storage period. Extension of the cold storage period up to 14 days resulted in further losses in the content of the analysed compounds. Regardless of the milk type, significantly greater decrease of pesticides was detected in probiotic beverages prepared from the mixture of two monocultures ( $L b$. acidophilus $\llcorner A-5$ and Bifidobacterium BB-12), than in beverages containing only $L A-5$. The losses of content of the analysed compounds in all fermented beverages were higher by several percent in beverages manufactured from goat milk. This was probably due to differences in the properties of cow and goat milk.

\section{Acknowledgments}

The authors are grateful to Prof. Mikołaj Protasowicki, the head of the Toxicology Department, and Prof. Małgorzata Jasińska, the head of Department of Dairy Technology and Food Storage, Faculty of Food Sciences and Fisheries for their kindness and support. 


\section{Usporedba utjecaja odabranih probiotičkih sojeva na promjene u koncentraciji rezidua organokloriranih pesticida u fermentiranim napitcima od kravljeg i kozjeg mlijeka tijekom hladnog skladištenja}

\section{Sažetak}

U ovom je radu ispitivan utjecaj odabranih probiotičkih monokultura na smanjenje koncentracije rezidua organokloriranih pesticida (OCP) tijekom skladištenja fermentiranih napitaka od kravljeg i kozjeg mlijeka. Tijekom hladnog skladištenja dodatak monokultura ili mješovitih kultura probiotičkih sojeva klasično proizvedenim jogurtima rezultirao je snižavanjem koncentracije OCP u ispitivanim uzorcima. Produljenjem perioda skladištenja na 14 dana došlo je do dodatnog snižavanja analiziranih rezidua. Veći pad koncentracije rezidua pesticida zabilježen je u jogurtima koji su sadržavali mješovitu kulturu (Lb. acidophilus LA-5 i Bifidobacterium BB-12) nego u uzorcima koji su sadržavali samo soj LA-5. Takvi trendovi su utvrđeni u svim uzrocima s mješovitom probiotičkom kulturom, neovisno o vrsti mlijeka korištenoj za njihovu proizvodnju. Najveći pad koncentracije pesticida zabilježen je tijekom 14 dana hladnog skladištenja i kretao se između 39 \% to 20,7 \%, te je bio nešto viši u uzorcima kozjeg jogurta.

\section{Ključne riječi: fermentirani napitci, probiotičke bakterije, Lb. acidophilus, Bifidobacterium, rezidue organokloriranih pesticida (OCP)}

\section{References}

1. Abou Donia, M.A., Abou-Arab, A.A.K., Enb, A., El-Senaity, M.H., Abd-Rabou, N.S. (2010): Chemical composition of raw milk and the accumulation of pesticide residues in milk products. Global Veterinaria 4 (1), 6-14.

2. AOAC (1995): Official Methods of Analysis of the AOAC international, $16^{\text {th }}$ ed. Method 970.12. Association of Official Analytical Chemists International. Washington, DC, USA.

3. Abou-Arab, A.A.K. (1997): Effect of Ras cheese manufacturing on the stability of DDT and its metabolites. Food Chemistry 59, 115. https://doi.org/10.1016/s0308-8146(96)00214-2

4. Abou-Arab, A.A.K. (1999): Effect of processing and storage of dairy products on lindane residues and metabolites. Food Chemistry 64, 467-473. https://doi.org/10.1016/s0308-8146(98)00126-5

5. Biegańska, J. (2007): A model study of pesticide biodegradation in soil. Biology Bulletin 34 (1), 76-85. https://doi.org/10.1134/s1062359007010116

6. Blüthgen, A. (2000): Contamination of milk from feed. Bulletin of the International Dairy Federation 356, 43-47.

7. Commission Directive 2002/63/EC (2002): Commission Directive 2002/63/EC of 11 July 2002 establishing Community methods of sampling for the official control of pesticide residues in and on products of plant and animal origin and repealing Directive 79/700/EEC (Text with EEA relevance).

https://doi.org/10.5771/9783845271873-920
8. Costa, R.G., Beltrão Filho, E.M., Sousa, S., Cruz, G.R.B., Queiroga, R.C.R.E., Cruz, E.N. (2016): Physicochemical and sensory characteristics of yogurts made from goat and cow milk. Animal Science Journal 87, 703-709. https://doi.org/10.1111/asj.12435

9. Cygański, A. (1993): Metody spektroskopowe w chemii analitycznej, WNT, Warszawa Poland.

10. EHC (1991): Environmental Health Criteria 124. Lindane. WHO/IPCS Geneva 1991.

11. Eissa, E.A., Babiker, E.E., Yagoub, A.E.A. (2011): Physicochemical, microbiological and sensory properties of Sudanese yogurt (zabadi) made from goat's milk. Animal Production Science 51, 53-59. https://doi.org/10.1071/an09126

12. Gomes, J.J.L., Duarte, A.M., Batista, A.S.M., de Figueiredo, R.M.F., de Sousa, E.P., de Souza, E.L., Queiroga, R.C.R.E. (2013): Physicochemical and sensory properties of fermented dairy beverages made with goat's milk, cow's milk and a mixture of the two milks. LWT-Food Science and Technology 54, 18-24. https://doi.org/10.1016/j.lwt.2013.04.022

13. Górska, J. (2015): Produkty kozie. Rynek produktów kozich na świecie. Forum Mleczarskie Biznes 1, 20. [http://www.forummleczarskie.pl/RAPORTY/446/rynekproduktow-kozich-na-swiecie/ access from 15.06.18] [Goat products. Market goat products in the world]

14. Mrema, E.J., Rubino, F.M., Brambilla, G., Moretto, A., Tsatsakis, A.M., Colosio, C. (2013): Persistent organochlorinated pesticides and mechanisms of their toxicity. Toxicology 307, 74-88. https://doi.org/10.1016/j.tox.2012.11.015 
15. Ortiz-Hernández, M.L., Sánchez-Salinas, E., DantánGonzález, E., Castrejón-Godínez, M.L. (2013): Pesticide Biodegradation: Mechanisms, Genetics and Strategies to Enhance the Process. In: R. Chamy (Ed.), Biodegradation - Life of Science. InTech, Access from: https://www. intechopen.com/books/biodegradation-life-of-science/ pesticide-biodegradation-mechanisms-genetics-andstrategies-to-enhance-the-process https://doi.org/10.5772/56098

16. Park, Y.W., Juarez, M., Ramos, M., Haenlein, G.F.W. (2007): Physico-chemical characteristics of goat and sheep milk. Small Ruminant Research 68, 88-113. https://doi.org/10.1016/j.smallrumres.2006.09.013

17. Phillips, T.M., Seech, A.G., Lee, H., Trevors, J.T. (2005): Biodegradation of hexachlorocycloheksane $(\mathrm{HCH})$ by microorganisms. Biodegradation 16 (4), 363-392. https://doi.org/10.1007/s10532-004-2413-6

18. PN-ISO 488: 2010. Mleko - Oznaczanie zawartości tłuszczu - Tłuszczomierze Gerbera. [Milk - Determination of fat content - Gerber's fat metres]

19. Rafalska, A., Krauze, M. (2016): Cholinesterases as indicators used in biological monitoring of exposure to pesticides. Nauki Przyrodnicze 4 (14), 3-13.

20. Salem, N.M., Ahmad, R., Estaitieh, H. (2009): Organochlorine pesticide residues in dairy products in Jordan. Chemosphere 77, 673-678. https://doi.org/10.1016/j.chemosphere.2009.07.045

21. Stams, A.J.M., Zehnder, A.B., Bachmann, A. (1991): Relative biochemical reactivity of three hexachlorocyclohexane isomers. Ecotoxicol. Environ. Safety 21, 128-136.
22. Statistical Yearbook (2016): Rocznik Statystyczny Rzeczpospolitej Polskiej, Główny Urząd Statystyczny, Warszawa, 2016. [Statistical Yearbook of the Republik of Poland, Central Statistical Office, Warsaw, 2016]

23. Sudharshan, S., Mallavarapu, M., Bolan, N., Naidu, R. (2013): Effect of seaweeds on degradation of DDT in soils. Water Air and Soil Pollution Journal 224, 1715. https://doi.org/10.1007/s11270-013-1715-x

24. Wang, B., Liu, W., Liu, X., Franks, A.E., Teng, Y., Luo, Y. (2017): Comparative analysis of microbial communities during enrichment and isolation of DDT-degrading bacteria by culture-dependent and -independent methods. Science of the Total Environment 590-591, 297-303. https://doi.org/10.1016/j.scitotenv.2017.03.004

25. Witczak, A., Mituniewicz-Małek, A., Dmytrów, I. (2013): Assessment of daily intake of organochlorine pesticides from milk in different regions of Poland. Journal of Environmental Science and Health Part B 48, 83-91. https://doi.org/10.1080/03601234.2013.726589

26. Witczak, A. (2017): Dioxins and Dioxin- like Compounds in Food. In: A. Witczak \& Z. Sikorski (Ed.), Toxins and other harmful compounds in foods (pp. 277-306). USA: CRC Taylor \& Francis Group. https://doi.org/10.1201/9781315368535

27. Zhang, H., Chai, Z.F., Sun, H.B., Zhang, J.L. (2006): A survey of extractable persistent organochlorine pollutants in Chinese commercial yoghurt. Journal of Dairy Science 89(5), 1414-1419. https://doi.org/10.3168/jds.s0022-0302(06)72210-x 